Gut, 1961, 2, 297

\title{
Serum haptoglobin in liver disease
}

\author{
ROGER WILLIAMS, BARBARA E. SPEYER, AND \\ BARBARA H. BILLING
}

From the Department of Medicine, Royal Free Hospital, London

SYNOPSIS Serum haptoglobin levels have been measured in 115 cases of widely differing liver disease. Although low levels were found in some cases of cirrhosis and a number of patients with obstructive jaundice had increased levels, $70 \%$ of the values fell within the normal range. The estimation was of no help in distinguishing between intra- and extrahepatic obstructive jaundice. A characteristic pattern was observed in infective hepatitis, and a falling serum haptoglobin in the presence of increasing jaundice is diagnostic of the latter condition. The cause of these changes is uncertain. Low levels could not be accounted for by increased red cell breakdown and there was no correlation with the serum albumin level.

Prednisolone therapy produced a rise in serum haptoglobin level in cirrhosis, which was accompanied by an improvement in liver function. Temporary rises in level were observed in intrahepatic obstructive jaundice and were probably due to a non-specific effect of prednisolone. In the latter condition norethandrolone therapy was often associated with high levels.

Haptoglobin is an $\alpha_{2}$ globulin which has the specific property of combining stoichiometrically with haemoglobin (Jayle, Boussier, and Tonnelat, 1956). The complex formed cannot pass through the glomerulus and the level of haptoglobin is an important factor in determining the renal threshold for haemoglobin. It is not surprising to find a reduced serum haptoglobin level in cases of intravascular haemolysis although the mechanism for the reduction in cases of haemolytic disease with extravascular erythrocyte destruction is not known (Brus and Lewis, 1959; Owen, de Gruchy, and Smith, 1960). The variations in level encountered in other diseases are also difficult to interpret, particularly since fever (Nyman, 1959) and non-specific stresses (Owen, Podanyi, and Smith, 1961a) may cause raised values. Low serum haptoglobin values have been reported in some cases of cirrhosis and raised levels in obstructive jaundice (Jayle and Vallin, 1952; Nyman, 1959; Owen, Mackay, and Got, 1959). Recently, Owen et al. (1961b) have stressed the value of this estimation in the differential diagnosis of jaundice; as a single test it proved slightly more effective than the serum alkaline phosphatase, albumin, or flocculation tests.

This paper describes findings in widely differing cases of liver disease. Serial estimations have been performed since little attention has previously been paid to spontaneous fluctuations, which could seriously affect the value of a single estimation. The changes in serum haptoglobin observed have been related to the degree of haemolysis present and the effect of prednisolone and other therapy has been assessed.

\section{PATIENTS STUDIED}

One hundred and fifteen cases were studied. These were divided into five main groups:-Cirrhosis (40), obstructive jaundice (33), infective hepatitis (27), congenital hyperbilirubinaemia (10), and miscellaneous (5), as shown in Table I. Two cases of portal cirrhosis and one alcoholic patient with cirrhosis are included in the group of intrahepatic obstruction since they were deeply jaundiced with all the features of cholestasis. Indeed the two patients with portal cirrhosis had initially been mistaken for cases of primary biliary cirrhosis.

\section{METHODS}

Haptoglobin was estimated by adding standard methaemoglobin solution to serum and determining the peroxidase activity of the resulting methaemoglobin complex colorimetrically (Owen, Better, and Hoban, 1960). Haptoglobin concentration is expressed in terms of bound methaemoglobin (M.Hb). The mean value for 31 normal subjects was found to be $81.0 \mathrm{mg} . / 100 \mathrm{ml}$. with a range (mean \pm 2 S.D.) of 8 to $154 \mathrm{mg} . / 100 \mathrm{ml}$. 
TABLE I

PATIENTS STUDIED

\begin{tabular}{lr} 
Diagnosis & No. of Cases \\
\hline Cirrhosis & 19 \\
Post-hepatitis or cryptogenic & 6 \\
Alcoholic & 5 \\
Juvenile & 10 \\
Haemochromatosis & \\
Obstructive jaundice (intrahepatic) & 18 \\
Primary biliary cirrhosis & 1 \\
Chronic chlorpromazine jaundice & 2 \\
Portal cirrhosis with cholestasis & \\
Alcoholic cirrhosis with cholestasis' & 1 \\
Unexplained & 2 \\
Obstructive jaundice (extrahepatic) & \\
Carcinoma & 6 \\
Stricture & 3 \\
Infective hepatitis & 27 \\
Congenital hyperbilirubinaemic & \\
Gilbert & \\
Dubin-Johnson & 8 \\
Miscellaneous & 2 \\
Secondary biliary cirrhosis & \\
Cirrhosis with hepatocellular carcinoma & \\
Congenital hepatic fibrosis & 1 \\
Total & 2 \\
'See text. & 2
\end{tabular}

This agrees reasonably weil with the series of 152 normals studied by Smith and Owen (1961), which gave a mean value of $93 \mathrm{mg} . / 100 \mathrm{ml}$. with a range (mean \pm S.D.) of 13 to $173 \mathrm{mg} . / 100 \mathrm{ml}$. In some cases the serum was also examined by starch gel electrophoresis using the vertical technique of Smithies (1955). The concentrations of the serum protein fractions were determined by the biuret method together with electrophoresis and scanning. Serum total bilirubin (Malloy and Evelyn, 1937) and serum alkaline phosphatase (King and Wootton, 1959) have also been measured.

Red cell survival and blood volume were determined by the radioactive chromium technique (Veall and Vetter, 1958). The results were expressed in terms of the $\mathrm{Cr}^{51}$ red cell half-life $\left(\mathrm{t} \frac{1}{2}\right)$ and were not corrected for chromium elution. An estimate of peripheral haemoglobin destruction was obtained by multiplying the fraction of red cells destroyed daily by the total circulating haemoglobin. Since the chromium red cell half-life is less than the true half-life, the calculation overestimates the amount of haemoglobin destroyed but should give comparable values for different subjects. In a normal person the haemoglobin destruction rate is approximately $250 \mathrm{mg}$./ kg./day.

\section{RESULTS}

1 CIRRHOSIS Serum haptoglobin was reduced $(<8$ mg./100 ml.) in six of the 19 patients with posthepatitis or cryptogenic cirrhosis. In the others the level was usually in the lower part of the normal range, 11 cases having a value of less than $20 \mathrm{mg}$./

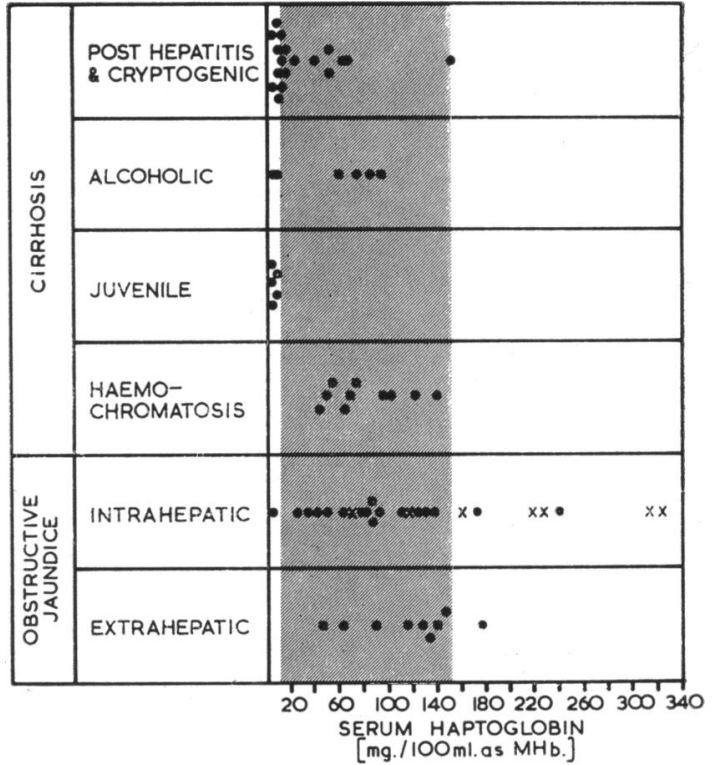

FIG. 1. Serum haptoglobin levels in cirrhosis and obstrucctive jaundice

$x=$ Norethandrolone therapy.

The hatched area indicates the normal range.

$100 \mathrm{ml}$. (Fig. 1). In general the patients with liver cell decompensation, as shown by ascites or jaundice, had a low serum haptoglobin and the wellcompensated cirrhotic patients had a higher level. There were, however, many exceptions; for instance, three of the 11 patients with a haptoglobin level of less than $20 \mathrm{mg} . / 100 \mathrm{ml}$. were out-patients with a well-compensated cirrhosis and two casss with levels of 66 and $71 \mathrm{mg} . / 100 \mathrm{ml}$. had ascites and impending hepatic coma. This also applied to the alcoholic patients with cirrhosis. Two of the six cases studied had reduced levels; one of these was clinically well, the other in terminal hepatic coma.

The five cases of 'juvenile' cirrhosis (Bearn, Kunkel, and Slater, 1956) had a reduced serum haptoglobin. These patients had active disease with raised serum bilirubin and transaminase levels, and four were subsequently treated with prednisolone as described later.

In idiopathic haemochromatosis the serum haptoglobin level was within the normal range. Although the patients had a definite cirrhosis histologically none showed evidence of liver cell failure and routine liver function tests were normal.

Considering all the cases of cirrhosis together, there was no correlation between the serum albumin and the haptoglobin level $(r=0.113 p>0.1)$.

2 ObSTRUCTIVE JaUndice (INTRAHEPATIC) The patients in this group had all been jaundiced for 
some months. The level of serum haptoglobin was very variable and not related to the underlying cause of the cholestasis. In 16 of the 24 cases it was within the normal range (Fig. 1). Seven had an increased concentration. In five patients the serum haptoglobin was over $200 \mathrm{mg} . / 100 \mathrm{ml}$. and two patients with primary biliary cirrhosis had levels of 314 and $324 \mathrm{mg}$. $/ 100 \mathrm{ml}$. respectively. When examined by starch gel electrophoresis those sera with high levels showed a normal haptoglobin pattern. The only patient with a low value had repeated readings of $0 \mathrm{mg} . / 100 \mathrm{ml}$. There was no evidence of an inhibitory factor in the serum and the absence of serum haptoglobin was confirmed by starch gel electrophoresis. Clinically she had primary biliary cirrhosis and differed in no way from the other patients with normal or raised levels. She probably has a genetically determined anhaptoglobinaemia (Allison, 1959).

Serial readings were obtained in 12 patients with primary biliary cirrhosis. In four of these the serum haptoglobin remained constant. In another four the level of serum haptoglobin increased or decreased with the serum bilirubin level but in the remaining four the level fluctuated for no obvious reason.

Since five of the seven patients with raised serum haptoglobin levels in this group were receiving norethandrolone (Nilevar) therapy for pruritus, the effect of this drug on serum haptoglobin was investigated. Two patients were studied before and during its administration. Their haptoglobin levels rose from 26 to 256 and from 86 to $218 \mathrm{mg}$. $/ 100 \mathrm{ml}$. and at the same time they became more jaundiced, their serum bilirubin levels rising from 3.0 to 10.6 and from 3.4 to $30 \mathrm{mg} . / 100 \mathrm{ml}$. respectively; no appreciable changes in serum alkaline phosphatase were recorded.

Extrahepatic The serum haptoglobin was within the normal range with the exception of one patient, who had a raised level of $178 \mathrm{mg} . / 100 \mathrm{ml}$. This was a young girl with congenital hepatic fibrosis, in whom the bile duct had been damaged at operation. One patient with a bile duct stricture and a level of $138 \mathrm{mg} . / 100 \mathrm{ml}$. had a previous reading when he was not jaundiced of $62 \mathrm{mg} . / 100 \mathrm{ml}$.

Considering all the cases of intra- and extrahepatic obstructive jaundice together (whether on or off Nilevar) no correlation was found between the haptoglobin level and the height of the serum bilirubin $(r=0.08, P>0.1)$. There was, however, a slight though significant correlation $(r=0.360$, $\mathbf{P}<0.05$ ) between the serum concentration of haptoglobin and alkaline phosphatase.

3 INFECTIVE HEPATITIS Serial readings were obtained in seven of the 27 cases and showed a characteristic pattern. Five of these patients had been treated with prednisolone but the same pattern was observed in the other patients who were not given steroids. Fig. 2 shows the course of a patient who had been jaundiced for one week before admission. The initial serum haptoglobin was low but as the serum bilirubin fell the haptoglobin level rose. Subsequently, the level fell again. The inverse relationship between serum bilirubin and haptoglobin during the early recovery phase of hepatitis

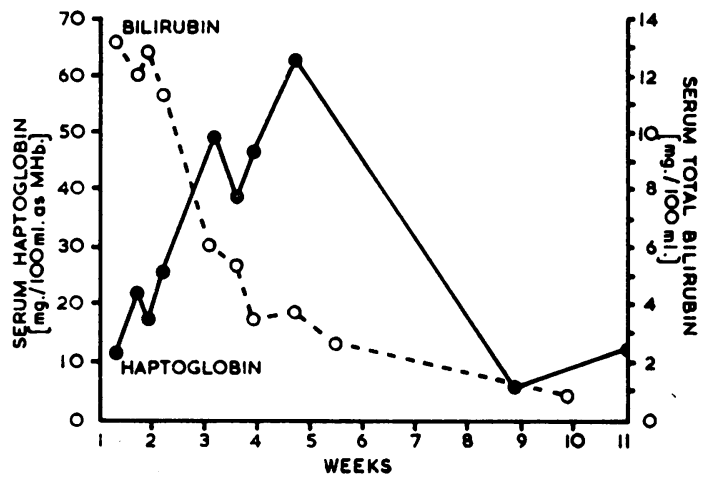

FIG. 2. Changes in serum bilirubin and haptoglobin levels in a patient with infective hepatitis, who had been jaundiced for one week before admission.

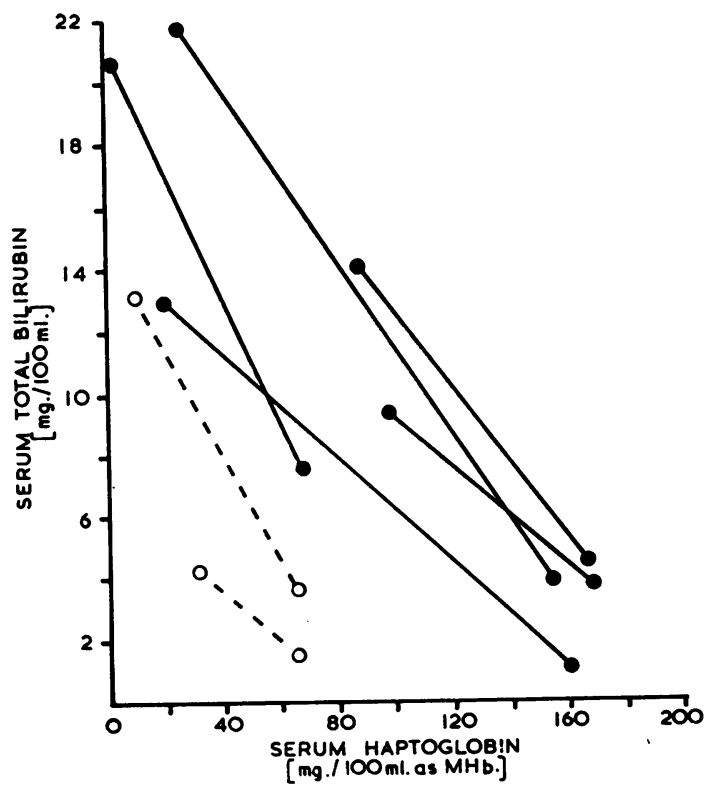

FIG. 3. The inverse relationship between serum haptoglobin and bilirubin levels during the early recovery phase of infective hepatitis.

= prednisolone ti.erapy. 


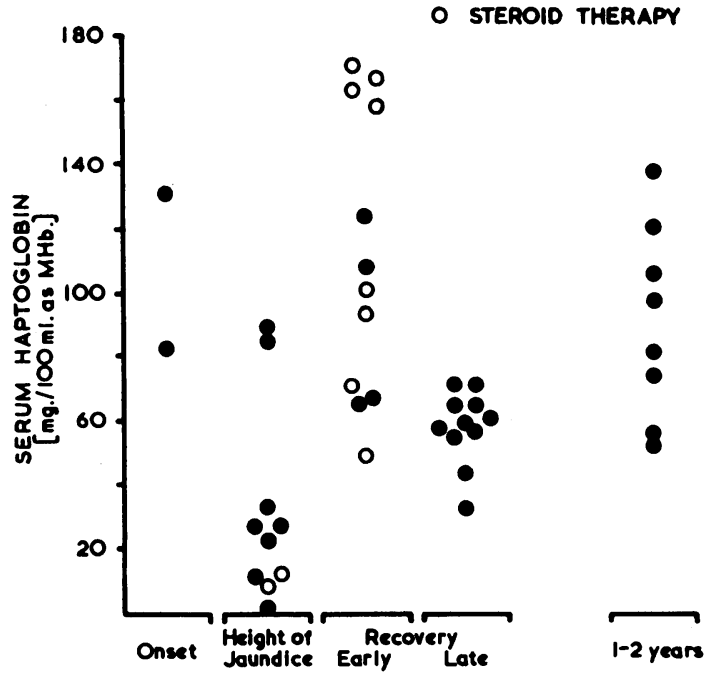

FIG. 4. Serum haptoglobin levels in 27 cases of infective hepatitis at varying stages of the disease.

is also shown in Fig. 3. Two cases were seen much earlier in the course of the disease shortly after jaundice had been noticed. The first haptoglobin readings were $128 \mathrm{mg} . / 100 \mathrm{ml}$. and $84 \mathrm{mg} . / 100 \mathrm{ml}$. but as jaundice increased during the first week of sequently, during recovery the level rose and then fell again as described above.

The results in the remainder of the patients, in whom serial readings were not performed, have been related to the stage of the disease and are shown together with the results in the serial cases (one reading for each stage) in Fig. 4. Although the levels at each stage showed a wide scatter, as might be expected from the different degrees of severity of with the sequence described above. It can be seen that the haptoglobin levels during recovery, although within the normal range, are below the normal mean. In a few patients who have been followed subsequently, the level rose slowly during the next few admission the serum haptoglobin level fell. Subthe cases, the variation between stages is consistent

months. This agrees with results from a separate group of patients, who had had hepatitis one to two years previously, and who showed, in general, higher levels distributed around the normal mean. Clinically these patients were well though two had a slightly raised serum bilirubin.

4 CONGENITAL HYPERBILIRUBINAEMIA The serum haptoglobin levels, together with relevant data on these patients, are shown in Table II. Although in none of the cases did the level fall below the lower limit of the normal range $(8 \mathrm{mg}$. $/ 100 \mathrm{ml}$.), in four of the eight patients with Gilbert's disease the serum haptoglobin was $20 \mathrm{mg} . / 100 \mathrm{ml}$. or less. In two of these the red cell survival was measured and found to be normal whereas in two other patients with Gilbert's disease, who had higher haptoglobin levels, the survival was slightly reduced.

5 Miscellaneous The two patients with congenital hepatic fibrosis had low serum haptoglobin levels (4 and $5 \mathrm{mg}$. $/ 100 \mathrm{ml}$. respectively). Routine liver function tests in these cases were normal apart from a slightly raised serum alkaline phosphatase. The one patient with a secondary biliary cirrhosis had a level of $7 \mathrm{mg} . / 100 \mathrm{ml}$. In this patient biliary obstruction had been successfully relieved surgically but had nevertheless progressed to the stage of terminal liver failure. The two patients with cirrhosis with hepatocellular carcinoma were deeply jaundiced and had serum haptoglobin levels of 116 and 204 mg. $/ 100 \mathrm{ml}$.

\section{RELATION WITH INCREASED HAEMOLYSIS}

In infective hepatitis no relation has been found between the initial haptoglobin level and the increased rate of haemolysis present, as measured either by $\mathrm{Cr}^{51}$ red cell half-life or by the calculated rate of peripheral haemoglobin destruction (Table III). The serum haptoglobin level fluctuates so much during the course of the hepatitis that any such relationship would be unlikely, for the rate of disappearance

TABLE II

SERUM HAPTOGLOBIN CONCENTRATIONS IN 10 CASES OF CONGENITAL HYPERBILIRUBINAEMIA

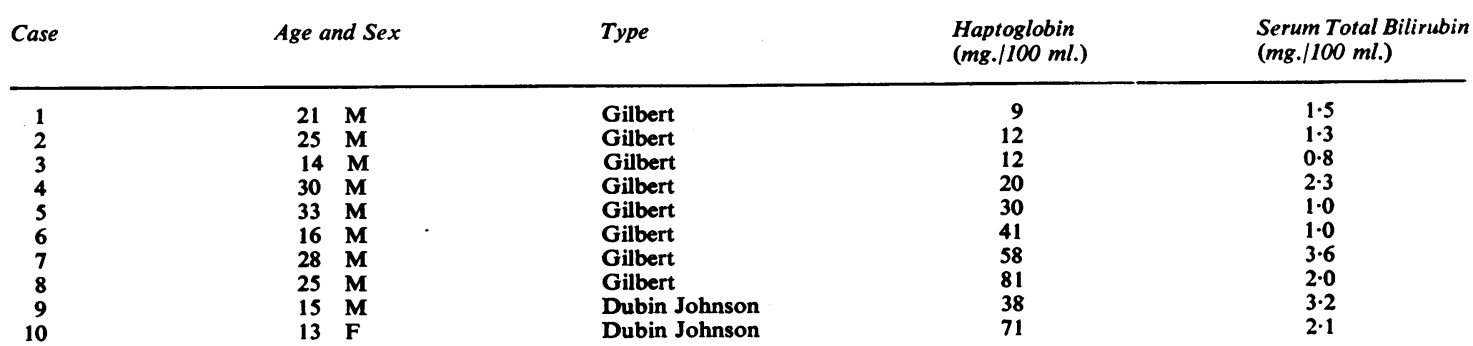


of the radioactive cells during this same period does not change (Williams, Pitcher, and Billing 1962).

The calculated peripheral destruction per day depends not only on the rate of cell breakdown, but also on the total amount of circulating haemoglobin and consequently, if this is reduced, as in Case 5 (Table III), who was anaemic, increased haemolysis may not necessarily indicate an increase in the amount of haemoglobin being destroyed. The results show that in cirrhosis and extrahepatic obstruction patients with similar peripheral haemoglobin destruction rates have widely differing haptoglobin levels. A low serum haptoglobin may be found in cirrhosis when there is little increased haemolysis (Case 1) and in obstructive jaundice a high level may occur (Case 9) when there is a marked increase in the rate of haemoglobin destruction. The poor correlation between haptoglobin level and increased red cell breakdown in congenital hyperbilirubinaemia has already been described.
EFFECT OF PREDNISOLONE THERAPY

There is some evidence that giving corticosteroid produces a rise in serum haptoglobin (Brus and Lewis, 1959). The main difficulty in assessing the results in patients with liver disease is therefore to determine which changes are directly due to a nonspecific effect of prednisolone and which are secondary to any improvement in liver function that may result. The latter appeared to be the more important factor in the cases of active juvenile cirrhosis treated with prednisolone (Table IV). Three of these showed a definite rise in serum haptoglobin level and in each case liver function also improved with a fall in serum transaminase and serum bilirubin levels. In the fourth case, however, there was no improvement and here the serum haptoglobin remained low.

In obstructive jaundice the problem is simpler, for although giving prednisolone may produce a fall in

TABLE III

SERUM HAPTOGLOBIN LEVEL RELATED TO RATE OF RED CELL BREAKDOWN AND PERIPHERAL HAEMOGLOBIN DESTRUCTION.

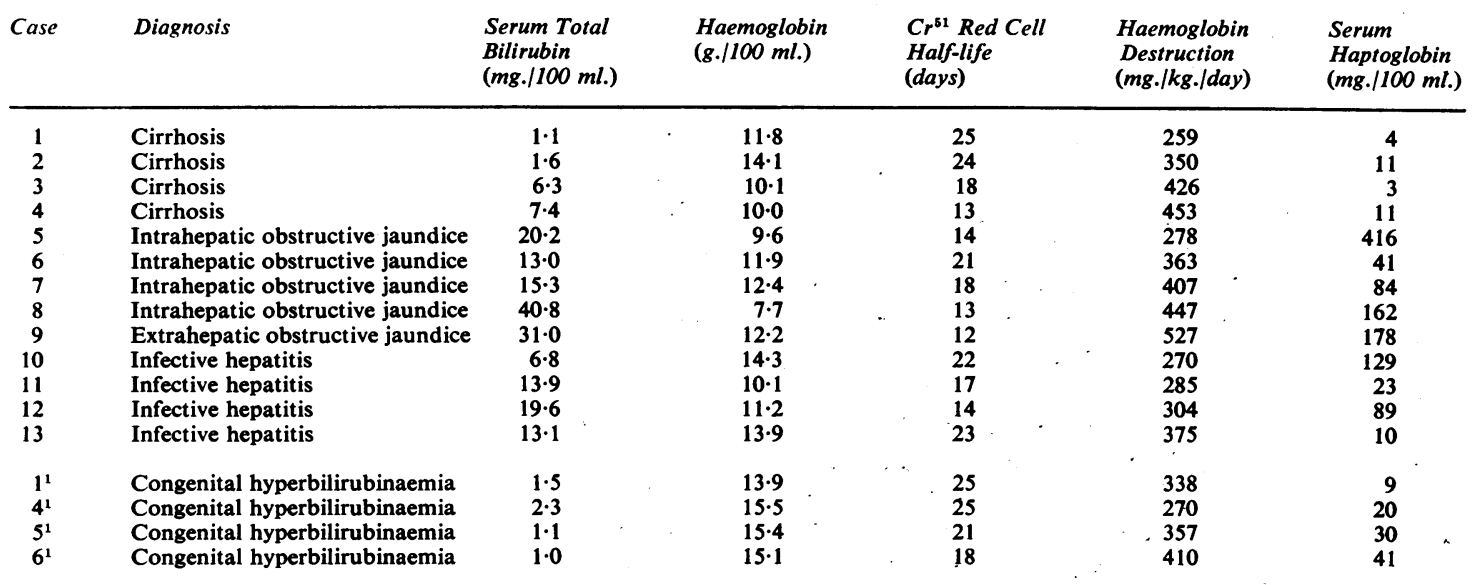

${ }^{1}$ These are the same case numbers as in Table II.

TABLE IV

SERUM HAPTOGLOBIN AND BILIRUBIN LEVELS IN FOUR CASES OF ACTIVE 'JUVENILE' CIRRHOSIS BEFORE AND AFTER PREDNISOLONE THERAPY.

\begin{tabular}{|c|c|c|c|c|c|}
\hline \multirow[t]{2}{*}{ Case } & \multicolumn{2}{|c|}{ Serum Total Bilirubin ( $\mathrm{mg} . / 100 \mathrm{ml}$ ) } & \multicolumn{2}{|c|}{ Serum Haptoglobin (mg./100 ml.) } & \multirow[t]{2}{*}{ Duration of Therapy } \\
\hline & Before & After & Before & After & \\
\hline $\begin{array}{l}1 \\
2 \\
3 \\
4\end{array}$ & $\begin{array}{l}3 \cdot 0 \\
8 \cdot 0 \\
4 \cdot 5 \\
6 \cdot 3\end{array}$ & $\begin{array}{r}1.0 \\
1.0 \\
2.0 \\
12.3\end{array}$ & $\begin{array}{l}3 \\
7 \\
8 \\
3\end{array}$ & $\begin{array}{r}23 \\
49 \\
43 \\
4\end{array}$ & $\begin{array}{l}4 \text { months } \\
4 \text { months } \\
3 \text { weeks } \\
5 \text { weeks }\end{array}$ \\
\hline
\end{tabular}




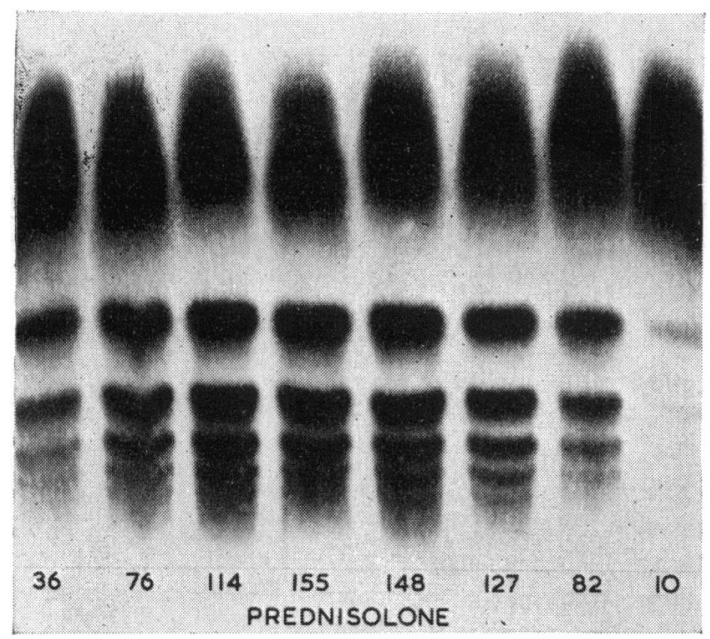

F1G. 5. Starch gel electrophoresis of sera from a patient with intrahepatic obstructive jaundice showing an unaltered haptoglobin pattern despite marked variation in level with prednisolone therapy.

serum bilirubin, this is not very marked and the effect is purely temporary. Prednisolone was given to five of the patients with chronic intrahepatic obstruction. In one, the haptoglobin level was already falling and continued to do so despite prednisolone therapy. Two others showed a slight rise in serum haptoglobin coincident with a slight fall in serum bilirubin, these changes being reversed when treatment was discontinued. The remaining two showed a marked and rapid rise in serum haptoglobin (36 to $155 \mathrm{mg} . / 100 \mathrm{ml}$. over eight days, and 41 to $102 \mathrm{mg}$. $/ 100 \mathrm{ml}$. over two weeks respectively), whereas the serum bilirubin fell only slightly in the first and rose steadily in the second patient throughout the period of observation. Subsequently there was an equally rapid fall, though steroid therapy was continued in one patient. The serum of one of these was subjected to starch gel electrophoresis and it was found that the haptoglobin pattern remained unaltered in spite of changes in serum concentration ranging from 10 to $155 \mathrm{mg} . / 100 \mathrm{ml}$. (Fig. 5). It seems very likely that the response in these two patients was simply a non-specific effect of prednisolone on haptoglobin level.

Three cases of extrahepatic obstructive jaundice had steroid therapy. Two showed no change while the third had a slight rise in serum haptoglobin together with a slight fall in serum bilirubin, the response being similar to that seen in some of the cases of intrahepatic obstruction described above.

The effect of steroid therapy in infective hepatitis is also difficult to assess. There the serum haptoglobin rises markedly as the serum bilirubin begins to fall, this occurring with and without prednisolone therapy. The extent of the rise, however, is probably influenced by prednisolone as suggested by Fig. 3, although this is difficult to assess since the two groups were not of comparable severity and the higher levels reached in the treated cases may simply reflect the greater severity of disease.

\section{DISCUSSION}

Seventy per cent of the 73 patients with cirrhosis and obstructive jaundice had values falling within the normal range so that an isolated haptoglobin estimation is of limited value in the diagnosis of these conditions. Nevertheless, certain trends are apparent and the finding of an abnormally low level in the presence of liver disease is very suggestive of cirrhosis. This may be of considerable diagnostic help in the well-compensated patient, who shows few clinical signs. Nevertheless, there are many exceptions and the association in some patients of frank, decompensated liver disease with normal levels is unexplained. In obstructive jaundice the estimation seems of less value, for with one exception patients with extrahepatic obstruction had levels within the normal range. This is contrary to the findings of Owen et al. (1961b) who reported that $81 \%$ of their patients showed values over $150 \mathrm{mg}$./ $100 \mathrm{ml}$. However, our series is mainly composed of patients with carcinomatous obstructions whereas the majority of Owen's patients had obstruction due to gall stones. Nyman (1959) also found that it was only in the latter type of case, in which cholangitis is present, that the level was raised. The serum haptoglobin is of little value in distinguishing between intra- and extrahepatic obstructive jaundice, a point which has not been stressed before. It may, however, be of considerable value in the sometimes difficult differentiation between infective hepatitis and obstructive jaundice. A falling haptoglobin level in the presence of rapidly increasing jaundice is diagnostic of hepatitis (Owen et al., 1961b).

The mechanism of these changes in liver disease is uncertain. Owen and his colleagues (1959) found some correlation between the haptoglobin level and the serum albumin suggesting that the low levels were related to impaired hepatic synthesis of protein. This was not found by Nyman (1959) and in the present series there was no correlation with serum albumin. There does, however, appear to be a relation with the activity of the disease. The patients with active juvenile cirrhosis in whom the haptoglobin level rose with steroid therapy also showed improvement in liver function. Also, the majority of the decompensated cirrhotics had low levels whereas the patients with alcoholic cirrhosis or haemo- 
chromatosis, who had a quiescent type of lesion, had a serum haptoglobin within the normal range. Low levels, however, were found in two cases of congenital hepatic fibrosis, a condition in which there is little disturbance of liver function. In any case, there is as yet no direct evidence that the liver is the source of haptoglobin and the dramatic rises observed following infection and surgery have suggested a possible origin in connective tissue (Jayle and Boussier, 1955).

It is clear also that the low serum haptoglobin in cirrhosis cannot be attributed to haemolysis. Indeed Williams et al. (1962) have shown that increased haemolysis is common to all forms of jaundice, including that due to biliary obstruction, in which the haptoglobin level may be normal or high. Another possible explanation is altered oestrogen metabolism. Administration of these steroids has been shown to lower the serum haptoglobin (Borglin and Nyman, 1961) and it is known that their conjugation and excretion in liver disease is sometimes impaired (Cameron, 1957).

There was a slight, though significant, correlation between the level of serum haptoglobin and alkaline phosphatase. This suggests that the higher level in obstruction might be related to biliary retention. This presumes that haptoglobin is normally excreted in bile but in preliminary experiments we have only been able to demonstrate the presence of haptoglobin in bile in one case and this was a patient with an infection, who had a serum level of over 500 $\mathrm{mg} . / 100 \mathrm{ml}$. If biliary retention were a factor one would also expect a correlation with serum bilirubin which was not found. It is germane to consider here the effect of norethandrolone (Nilevar) therapy, a known cause of intrahepatic cholestasis. Cases of primary biliary cirrhosis receiving norethandrolone did tend to have higher serum haptoglobin values and the administration of this drug to two early cases caused a definite rise in level. This was accompanied by a rise in serum bilirubin although the serum alkaline phosphatase was unaltered. We cannot, therefore, be sure whether the rise in haptoglobin with norethandrolone is a secondary result of increased biliary retention or whether this drug has a non-specific effect similar to that of prednisolone. The abrupt and temporary rises in serum haptoglobin noted in some of the cases of intrahepatic obstruction are almost certainly due to a non-specific effect of prednisolone.

The alterations in serum haptoglobin in infective hepatitis are of interest. The fall in level as jaundice increases and the sudden rise with the onset of recovery are difficult to explain. If the rise were due to improvement in liver function then it is surprising that the level subsequently falls. Although the extent of the rise was greater in the patients on prednisolone therapy these were the most severe cases, and a definite increase occurred at this stage even in the patients who did not receive corticosteroids. Relatively few of these cases had serial estimations; Nyman (1959) has, however, reported a similar pattern in some of her cases of sporadic hepatitis.

In conclusion it is clear that there is as yet no satisfactory explanation for the changes in serum haptoglobin observed in differing types of liver disease. However, it is possible that turnover studies using haptoglobin labelled with radioactive iodine may help to elucidate this problem.

We should like to thank Professor Sheila Sherlock for her encouragement and advice. The work was supported by the Medical Research Council and Miles Laboratories Inc.

\section{REFERENCES}

Allison, A. C. (1959). Genetic control of human haptoglobin synthesis. Nature (Lond.), 183, 1312-1314.

Bearn, A. G., Kunkel, H. G., and Slater, R. J. (1956). The problem of chronic liver disease in young women. Amer. J. Med., 21, 3-15.

Borglin, N. E., and Nyman, M. (1961). The effect of estrogens on the haptoglobin level in the blood. Scand. J. clin. Lab. Invest., 13, 107-115.

Brus, I., and Lewis, S. M. (1959). The haptoglobin content of serum in haemolytic anaemia. Brit. J. Haemat., 5, 348-355.

Cameron, C. B. (1957). The liver and steroid hormone metabolism. Brit. med. Bull., 13, 119-125.

Jayle, M. F., and Boussier, G. (1955). Les séromucoìdes du sang, leurs relations avec les mucoprotéines de la substance fondamentale du tissu conjonctif. Expos. ann. Biochim. méd., 17, 157-194.

-, - and Tonnelat, J. (1956). Isolement à partir du sérum humain de la combinaison hémoglobine-haptoglobine à l'état homogène. Bull. Soc. Chim. biol. (Paris), 38, 343-349.

- and Vallin, J. (1952). Variations de la formule protéique du plasma au cours des affections hépatiques. Sem. Hôp. Paris, 28, 3133-3138.

King, E. J., and Wootton, I. D. P. (1959). Micro-analysis in Medical Biochemistry, 3rd ed. (reprint), pp. 82-84. Churchill, London.

Malloy, H. T., and Evelyn, K. A. (1937). The determination of bilirubin with the photoelectric colorimeter. J. biol. Chem., 119, 481-490.

Nyman, M. (1959). Serum haptoglobin: methodological and clinical studies. Scand. J. clin. Lab. Invest., 11, Suppl. 39.

Owen, J. A., Better, F. C., and Hoban, J. (1960). A simple method for the determination of serum haptoglobins. J. clin. Path., 13, 163-164.

-, Gruchy, G. C. de, and Smith, H. (1960). Serum haptoglobins in haemolytic states. Ibid., 13, 478-482.

- Mackay, I. R., and Got, C. (1959). Serum haptoglobins in hepatobiliary disease. Brit. med. J., 1, 1454-1457.

- Podanyi, R., and Smith, H. (1961a). The effect of surgery on serum haptoglobins. Proc. Ass. Clin. Biochem., 1, 89-91.

,,$---(1961 b)$. Serum haptoglobins and other tests in the diagnosis of hepatobiliary jaundice. Clin. Sci., 21, 189-197.

Smith, H., and Owen, J. A. (1961). The determination of haptoglobins in normal human serum. Biochem. J., 78, 723-728.

Smithies, O. (1955). Zone electrophoresis in starch gels: Group variations in the serum proteins of normal human adults. lbid., 61, 629-641.

Veall, N., and Vetter, H. (1958). Radioisotope Techniques in Clinical Research and Diagnosis. Butterworth, London.

Williams, R., Pitcher, C. S., and Billing, B. H. (1962). Red cell survival in infective hepatitis and other forms of jaundice. In preparation. 